\title{
The Rights of Minorities in International Law
}

\author{
Fatemeh Mihandoost ${ }^{1} \&$ Bah man Babajanian ${ }^{1}$ \\ ${ }^{1}$ Department of Law, Semnan Branch, Islamic A zad University, Semnan, Iran \\ Correspondence: Fatemeh Mihandoost, Department of Law, Semnan Branch, Islamic Azad University, Semnan, \\ Iran. Tel: 98-912-926-9700. E-mail: Fatemehmihandoost@yahoo.com
}

Received: June 9, 2016 Accepted: June 28, 2016 Online Published: July 31, 2016

doi:10.5539/jpl.v9n6p15 URL: http://dx.doi.org/10.5539/jpl.v9n6p15

\begin{abstract}
Today human right is of great importance. The existence of different minorities such as lingual, ethnic, racial, and religious minorities with different tendencies derived from different civilizations and cultures has brought about social and cultural varieties and differences in each country and also the emergence of this variety has resulted in the development of variety in a specific culture and ceremony in different countries. On the other hand, each country as a member of international society has to observe norms and principles accepted by international society. In other words, although preparation of constitution of each country depends on exclusive qualification of the country's people and government, it does not mean they are free in each law because international legitimacy of each country's government and constitution depends on observation of the accepted principles and the governing rules in international law. The subject of minorities was first introduced in Vienna Congress and today different minorities live in different countries. In international documents and treaties, a precise definition of minority has not been provided. The present article seeks to interpret minority rights according to international law and investigate minority rights in international law by using international documents.
\end{abstract}

Keywords: minority, international law, racial discrimination, international treaties, international documents

\section{Introduction}

There is no single definition of minority on which all scholars and international institutions agree although a lot of attempts have been made by the United Nations and specialized organizations to present a precise and comprehensive definition of minority. In the UN Secretary General's note on December 27, 1949 was written: (Although it is academically difficult to present a really precise definition of minority...in fact, "minority" is used in a more limited sense today. In the present, it is commonly applied to a specific group of society that has been distinguished from a superior group living in the country), (Arjmand, 1998) pp. 13-20. Article 27 of International Treaty of civil and political rights has not pointed out legal limitations in minorities' enjoying the right of their cultural identity; however, general viewpoints in nu mber 23 of Hu man Rights Committee point out: (None of the laws supported in article 27 must be exercised in a way or to the extension that is not in harmony with the other articles of the treaty), (Beigzadeh, 2000) pp. 20-22. Therefore, governments are not allowed to violate the other rights of minorities such as their right in enjoying non-discriminatory policies in order to take measures to support minorities to maintain their identity. In Treaty of Versailles, the committee supreme council established supporting minorities in new countries. All new substituting states had to sign minority rights treaties as a prerequisite to be diplomatically accepted. Although the new states were known to be official, they could not come into being prior to signing the final peace treaty. The topic had a distinction in German and Polish laws and as Polish law in Germany against German minority rights in Poland remained unprotected.

\subsection{A Literature Review}

\subsubsection{Minority Rights}

Minority rights are the normal individual rights as applied to me mbers of racial, ethnic, class, religious, linguistic or sexual minorities; and also the collective rights accorded to minority groups. Minority rights may also apply simply to individual rights of anyone who is not part of a majority decision (Smihula, 2008) p. 51-81.

Civil rights movements often seek to ensure that individual rights are not denied on the basis of me mbership in a minority group, such as global wo men's rights and global LGBT rights movements, or the various racial minority rights movements around the world (such as the Civil Rights Movement in the United States). 


\subsubsection{Minority Group}

Minority group is a term referring to a category of people differentiated from the social majority, i.e., those who hold the majority of positions of social power in a society, and may be defined by law. Rather than a relational "social group", as the term would indicate, "minority group" refers to the above-described. The differentiation can be based on one or more observable human characteristics, including: ethnicity, race, relig ion, caste, gender, wealth, health or sexual orientation. Usage of the term is applied to various situations and civilizations within history, despite its popular mis-association with a numerical, statistical minority (Barzilai, 2010). In the social sciences, the term "minority" is used to refer to categories of persons who hold fewer positions of social power .

The term "minority group" often occurs alongside a discourse of civil rights and collective rights which gained prominence in the 20th century. Members of minority groups are prone to different treatment in the countries and societies in which they live. This discrimination may be directly based on an individual's perceived membership of a minority group, without consideration of that individual's personal achievement. It may also occur indirectly, due to social structures that are not equally accessible to all. Activists campaigning on a range of issues may use the language of minority rights, including student rights, consumer rights, and animal rights (Phinney, 1989).

\section{Method}

The method applied in this research is descriptive-evaluative. Unlike historical researches, descriptive studies investigate the present. This type of research describes and interprets the existing circumstances and relationships. These researches study the present situation of a phenomenon or subject and evaluative researches describe the situation of a phenomenon at a specific time. This method does not suggest any hypothesis and does not study the relationship between variables and does not have any suggestions for further research but merely describes the present situation.

The research method used in this article is a review of the literature and interviews with experts as well as examining and comparing the rules and regulations and the existing notes at home and abroad on the rights of minorities in international law.

\section{Definition of Minority}

"Minority" literally means little amount and a small proportion and idio matically refers to a group of people in a country or city that is distinguished from the majority in terms of religion or race (Ariamanesh, 2011). A minority is a group that is not involved in governing the country and its number is s maller than the other part of the country population and its members, despite being the subjects of the government, have ethnic, religious, or lingual properties different from the rest of the country and have some sort of feeling of unity to maintain their culture, ceremonies, religion, or language.

A minority is a group of country's subjects that constitute a small proportion of population and do not participate in the country's government and have ethnic, religious, or lingual properties different from the majority of the society and there is some sort of feeling of unity that results from collective will for survival and they intend to achieve real and legal equality with the majority of people.

Islamic Conference Organization is the only international organization set up based on religion. Statement 47 of the eighth conference of leaders of member countries of Islamic Conference Organization in Tehran in 1977 and statement 46 issued after meeting of 25th conference of Ministers of Foreign Affairs of the member countries of this organization in 1998 in defending Muslim minorities living in non-member countries of Islamic Conference Organization reveal that this organization plans to identify and defend the rights of Muslim minorities. Following Qatar conference, a number of ambassadors and experts of this organization, in a meeting in Spain, investigated the ways to maintain Muslim minority rights and presented guidelines (Feinberg \& Gross, 1975). p. 199.

Another definition provided by secondary commission of the United Nations on minorities states: (A group that has a smaller number than the rest of the population of the country and is in non-governing situation and its members (the subjects of the government) have ethnic, religious, or lingual properties differing from the rest of the population and especially and continually have a feeling of unity through which they protect their culture, customs, relig ion, and language.

\subsection{The Other Definitions of Minorities}

A minority refers to a limited group which lives with the governing majority group in racial, cultural, and ethnic terms. Another definition of minority provided in Britannica states that "minority" used in political and social sciences refers to a small group of society living with the majority group of society by force. Minorities are not commonly involved in social issues and do not have privileges equal to the majority of society. In addition, 
minorities are politically weaker than the majority of the society.

Patrick Thornberry, the author of "International Law and Minorities Rights", defines a minority as a group that is not involved in the government and its population is smaller than the rest of the society, but its members are subjects of the country and have ethnic, re lig ious, or lingual properties different from the rest of population of the country and have a feeling of unity of benefits and cooperation in order to maintain their culture, customs, religion, or language (Ghari Seyed Fatemi, 2003).

Another definition points out minority has its own specific properties and if a group is different from the governing groups in ethnic, national, re lig ious, or lingual terms, it is called a minority (Haeri Yazdi, 1962).

\section{The Position of Minorities Rights in International Law}

The topic of minorities probably dates back to ancient times and establishment of great empires and it has gradually taken national, racial, and particularly relig ious aspects. But, in fact, in the early twentieth century, international law discusses this topic (Kemp, 2001) pp. 12-18. After the World Wars (I) and (II), major changes appeared in the boundaries of some countries and new nations entered international scene. This phenomenon resulted in racial, religious, and lingual mixture of nations and brought about settlement of minorities in these countries. With the establishment of international society, this suggestion was presented that some part of international society treaty covers the situation of minorities, but this suggestion was ignored due to disagreement of some governments; however, some rights and privileges were considered for them. Supporting minorities in international society included a regulation of international control according to which minorities could complain about their condition from their sovereign country directly to Nations Society Council which was responsible for control. This subject was discussed in the council and if there was a disagreement between the council and the beneficiary country, the subject was referred to International Justice Perpetual Court and the judgment of court on it was definite and irrevocable (Weller, 2005).

By investigating the legal documents, it was evident that international law protects minorities initially with the principles of equality and non-discrimination. Therefore, international society lacks an obligatory, comprehensive, legal, minority-specific docu ment. Artic le 27 of treaty of civil-political law and also statement of 1992 with the principles mentioned are considered as legal documents specific for minorities (Anwar, 2004). So, some believe that minorities enjoy just two rights in international law: right to live, or in other words, prohibition of genocide, and right of identity. The latter has been inspired from article 27 of treaty of civil-political law. Therefore, there is a long way to desirably identify and guarantee minority rights.

\section{Princi ples of Minority Rights}

In international law, there are some principles that explicitly express minorities and protect them in a specific way. These principles emphasize the point that all people including members of ethnic, racial, and religious minorities have the same basic rights as the other citizens of the society and must be able to enjoy these rights without discrimination. Some of the standard individual rights have a specific significance for ethnic and religious minorities. A mong these rights are social and cultural freedoms, freedom of assembly, freedom of speech, right for education and teaching in native language, freedom of organization, and the other principles mentioned in international rules.

Although the words "minority" and "ethnicity" have not been mentioned in the UN charter and the universal Declaration of Hu man Rights, in enforcing parts 3 and 4 of the first article and also articles 55 and 65 of the UN charter that considers observation of human rights and basic freedoms for all people without discrimination to race, gender, language, or religion, texts and documents have been ratified (Naserzadeh, 1951). They will be mentioned briefly below.

\section{The Problems of Minorities}

The fact that minority rights have been formulated and considered individually rather than socially is reflected in the current mechanism in the world. None of these rights has legal obligation and they are frequently open to people in minorities, not to minorities themselves (Pejic, 1997). p. 666-685. Once more the international treaty of civil and political rights is the starting point. Including ignoring the rights of minorities can be noted: unjustifiable arrests, unfair trials, executive lawlessness, suppression of free speech and undue domination of minorities (John, 2011).

The only obligatory governing procedure is the duty of countries in submitting periodical reports to Human Rights Committee (HRC) according to the criterion they have adopted to enforce the mentioned treaty (Phalsafi, 1996). The political consequences of this event are not ineffective, but they have no instant effect "on the current scene." Today the procedure of complaining inside a country faces lack of using article 41 . According to political 
considerations, it is unlikely to happen soon.

It seems that procedure of submitting individual complaints according to the first optional protocol to this treaty has been accepted more widely since the number of countries that have accepted this treaty has risen. Hu man Rights Committee has been successful at explaining the so-called contradiction of article 27 of the treaty, but its effects, if there are any, have been indirect toward minorities, except that the effectiveness of countries on committees' vie wpoints depends on their political requests and legal culture because committee's decisions have no legal obligation (Skrentny, 2009). The well-known case against Canada can be an example of this kind, the case of Sandra Lovelace, a red-skinned from Maliseet. After marrying a non-red-skinned, she lost her rights as a red-skinned following Canada's red-skinned laws; therefore, her right to live in "Tubik" was delayed. When referring to have her delayed rights after getting divorced, she was expelled. A question raised in this case was whether she belonged to Maliseet red-skinned people or not. The committee concluded that denying her identification as one of the red-skinned people in Maliseet was unfair. Eventually, Canada modified the red-skinned law.

Minorities, of course in a limited way, enjoy support of various international documents, the most explicit of which is 1960 Convention of UNESCO against discrimination on education. In addition, International Convention on the Elimination of all forms of Racial Discrimination (CERD) held in 1965 and Convention of 1948 on elimination and punishment of those who commit genocide have considered protecting minorities although they have not mentioned minorities explicitly. Similarly, a great number of social rights in Declaration of 1978 of UNESCO on race and racial prejudices and Declaration of 1981 of the United Nations Organization on elimination of any kind of prejudice and discrimination based on religion and beliefs have been mentioned. This general scheme of attempts to overcome problems to determine a legal obligatory definition of minorities from among the other purposes has been supported to achieve two goals. One is that it shows lack of definition definitely keeps open an extensive field for interpretations of minority and tendency to crime in declarations on a specific group whether it belongs to minorities or it actually does not exist at all (Thornberry, 1991).

A definition must help clarify ambiguities and express minority rights in international law. International organizations have the responsibility of controlling the observation of minority leg itimate and basic freedoms and rights by ratifying complementary and obligatory regulations. After World War (I) and before the establishment of UN, an international system was set up to protect minorities rights and in the treaties held between governments, it was prescribed that governments do not exercise any discrimination on minorities and give them the right to use their own language and religion (Zolein, 1995). The second goal is to clarify legal and political obstacles in definition of minority and explain the conditions in which minorities live. Presenting a comprehensive definition is impossible. However, it must not discourage and prevent attempts to define minorities precisely to hold legal tools relevant to their rights whenever possible.

\section{Conclusion}

Today, different organizations and institutions on protecting min ority rights have been established. To protect minorities, three elements of connection, cooperation, and unity must be taken into account. In fact, since there is no comprehensive definition, we must investigate the common points between different people so that we can protect minority rights.

Today, minorities are not supported, but they are also sometimes bothered and ignored. These unequal policies have resulted in discrimination of different rights in society.

In preparation of the Constitution of Isla mic Republic of Iran, plenty of attention has been paid to adapt with obligatory international treaties and documents on individual and social freedoms known in human rights and particularly with articles of declaration of minority rights. Due to lack of predicting a strong enforcement guarantee for the violation of the above rights, the presence of a little contradiction with the international system of human rights is undeniable. Some of these contradictions are somewhat inevitable owing to social and political context in Iran and also governing of Isla mic culture and can also be ignored in international law.

If minority rights are observed according to Constitution, contradiction of minority rights will not exist and the double flexibility of Iranian legislators on this subject compared to international obligatory documents and articles of treaties controlling them and international common law will be evident.

\section{References}

Amir Arjmand, A. (1998). World wide search: Reflections on human rights of law researches, issues 21-22, Shahid Beheshti University Publications, pp. 13-20.

Ariamanesh, B. (n.d.). Journal of law development researches, issue 4, 2011, the article on minorities rights in 
constitution and international law.

Barzilai, G. (2010). Communities and law: Politics and cultures of legal identities. University of Michigan Press.

Daniel Smihu la. (2008). National Minorities in the Law of the EC/EU in Romanian. Journal of European Affairs, $8(3), 51-81$.

Feinberg, J., \& Gross, H. (Eds.). (1975). Philosophy of law (p.199). Dickenson publishing company. Chicago.

Ghari Seyed Fatemi, M. (2003). treaties of human rights, law journal, issue 28, Publications of university of office of international law services.

Haeri Yazdi, M. (n.d.). Article on Islam and human rights declaration, journal of Tashayo, fourth year, Qom, 1341.

John, E. O. (2011). Rule of Law in Nigeria: Myth or Reality. The. J. Pol. \& L., $4,211$. http://dx.doi.org/10.5539/jpl.v4n 1p 211

Kemp, W. A. (Ed.). (2001). Quiet diplomacy in action; the OSCE High Commissioner on National Minorities. Martinus Nijhoff, p. 12-18.

Muhammad Anwar. (2004). State policies towards Muslim Minorities Sweden, Great Britain and Germany, parabolis, Berlin (EMZ).

Naserzadeh, H. (n.d.). Universal declarations of human rights, conventions, convention of 1951 in Geneva.

Pejic, J. (1997). Minority rights in international law. Human Rights Quarterly, 19(3), 666-685. http://dx.doi.org/10.1353/hrq.1997.0032

Phalsafi, H. (1996). The United Nations and mankind goal in journal on law researches, issue 18, Shahid Beheshti University Publications.

Phinney, J. S. (1989). Stages of ethnic identity development in minority group adolescents. The Journal of Early Adolescence, 9(1-2), 34-49. http://dx.doi.org/10.1177/0272431689091004

Skrentny, J. D. (2009). The minority rights revolution. Harvard University press.

The responsibility of governments in violation of human rights written by Amparosan Khoze Jil and translated by Ebrahim Beig zadeh, Journal of law researches, issues 29-30, Shahid Beheshti University Publications, 2000, pp. 20-22.

Thornberry, P. (1991). International law and the rights of minorities. Oxford Un iversity Press.

Weller, M. (2005). The Rights of Minorities in Europe, A commentary on the European Framework Convention for the protection of national minorities. Oxford University Press.

Zolein, N. (1995). Journal of law researches, issue 15, article on protection of minority rights in international law.

\section{Copyrights}

Copyright for this article is retained by the author(s), with first publication rights granted to the journal.

This is an open-access article distributed under the terms and conditions of the Creative Commons Attribution license (http://creativecommons.org/licenses/by/4.0/). 